\title{
SISTEM PERBANKAN SYARIAH DI INDONESIA
}

\section{Jurusan Perbankan Syariah Ekonomi Dan Bisnis Islam Universitas Islam Negeri}

\author{
Alauddin Makassar
}

Hijriani

90500120044

Email : hijirianihijiriani475@gmail.com

\begin{abstract}
Sharia banking in Indonesia has approached 24 years of age. This age implies that it such sharia banking has shifted to maturity phase. It has developed significantly compared to that of previous years. It can be observed from its average growth of its assets, DPK, PYD which is $45 \%$ higher than the years of 2000 up to 2014 . However, it is expected that it must able to make use of opportunities which are presently available to encounter challenges in the future, Consequently, it should be able to take advantage of supports and contributions of other such related parties as government, ulama, society, academicians, and students majoring in sharia banking as well. Kata kunci: development, sharia banking, Indonesia
\end{abstract}

Kata kunci: development, sharia banking, Indonesia

\begin{abstract}
Abstrak
Perbankan syariah di Indonesia telah mendekati usia 24 tahun. Usia ini menyiratkan bahwa perbankan syariah tersebut telah bergeser ke fase jatuh tempo. Perkembangannya cukup signifikan dibandingkan tahun-tahun sebelumnya. Hal ini dapat dilihat dari rata-rata pertumbuhan asetnya, DPK, PYD yang 45\% lebih tinggi dari tahun 2000 sampai dengan 2014. Namun demikian diharapkan harus mampu memanfaatkan peluang yang ada saat ini untuk menghadapi tantangan. Di masa depan, Oleh karena itu, harus dapat memanfaatkan dukungan dan kontribusi dari pihak terkait lainnya seperti pemerintah, ulama, masyarakat, akademisi, dan mahasiswa jurusan perbankan syariah juga. Kata kunci: perkembangan, perbankan syariah, Indonesia
\end{abstract}

Kata Kunci: perkembangan, perbankan syariah, Indonesia 
Perbankan syariah adalah sistem pertbankan yang pelaksanaannya berdasarkan hukum (syariah), Pembentukan sistem ini berdasarkan adanya larangan dalam agama islam untuk meminjamkan atau memungut pinjaman dengan mengenakan bunga pinjaman (bunga), serta larangan untuk berinve pada usaha-usaha yang bersifat (haram). Perbankan syariah memegang peran yang sangat penting dalam mendorong laju pertumbuhan ekonomi Indonesia, hal ini dapat dilakukan dengan menumbuhkan sektor investasi melalui dana pihak ketiga (DPK) dan menumbuhkan pembiayaan melalui pembiayaan yang diberikan (PYD) kepada masyarakat.

Undang Perbankan Syariah UU No. 21 Tahun 2008, dilihat dari sisi filosofi yuridis dan Sosiologis pada dasarnya telah menjawab kebutuhan rasa Keadilan Ummat Islam sebagai konsekuensi fluralisme hukum yang hidup dan tumbuh dalam dinamika masyarakat Indonesia.

\section{Sistem perbankan syariah}

Pengembangan sistem perbankan syariah di indonesia dilakukan dalam kerangka dualbanking system atau sistem perbankan ganda dalam kerangka Arsitektur Perbankan Indonesia (API), untuk menghadirkan alternatif jasa perbankan yang semakin lengkap kepada masyarakat Indonesia. Secara bersama-sama, sistem perbankan syariah dan perbankan konvensional secara sinergis mendukung mobilisasi dana masyarakat secara lebih luas untuk meningkatkan kemampuan pembiayaan bagi sektor-sektor perekonomian nasional.

Syariah adalah sistem pertbankan yang pelaksanaannya berdasarkan hukum (syariah), Pembentukan sistem ini berdasarkan adanya larangan dalam agama islam untuk meminjamkan atau memungut pinjaman dengan mengenakan bunga pinjaman (bunga), serta larangan untuk berinve pada usaha-usaha yang bersifat (haram). Sistem perbankan konvensional tidak dapat menjamin absennya hal-hal tersebut dalam investasinya, misalnya 
dalam usaha yang berkaitan dengan produksi makanan atau minuman haram, usaha media atau hiburan yang tidak Islami, dan lain-lain. Dalam Karakteristik sistem perbankan syariah yang beroperasi berdasarkan prinsip bagi hasil memberikan alternatif sistem perbankan yang saling menguntungkan bagi masyarakat dan bank, serta menonjolkan aspek keadilan dalam bertransaksi, investasi yang beretika, mengedepankan nilai-nilai kebersamaan dan persaudaraan dalam berproduksi, dan menghindari kegiatan spekulatif dalam bertransaksi keuangan. Dengan menyediakan beragam produk serta layanan jasa perbankan yang beragam dengan skema keuangan yang lebih bervariatif, perbankan syariah menjadi alternatif sistem perbankan yang kredibel dan dapat dinimati oleh seluruh golongan masyarakat Indonesia tanpa terkecuali.

Ada beberapa prinsip konsep Islam. Pertama, transaksi harus berasaskan manfaat (faedah). Menurut Islam, pemilik harta hanya boleh mendapat hasil yang merupakan fungsi manfaat dari pemakaian harta tersebut, baik oleh dirinya sendiri maupun oleh pihak lain. Kedua, uang diperlukan sebagai sarana pertukaran, karena tidak boleh digunakan sebagai komoditi. Kepemilikan uang semata-mata tidak boleh memberikan tambahan/keuntungan. Selanjutnya, transaksi harus spesifik dan transparan, karena dalam syariah Islam, transaksi harus didasarkan pada itikad baik, sehingga tidak boleh terdapat gharar.

Sejarah perbankan syariah pertama kali adalah pendirian sebuah bank Islam di Mesir, yaitu didirikannya Islamic Rural Bank di Kairo pada tahun 1963. Bank Islam pertama yang dimiliki oleh pihak swasta adalah Dubai Islamic Bank, yang didirikan pada tahun 1975 oleh sekelompok pengusaha muslim dari beberapa Negara. Perkembangan perbankan syariah secara internasional dimulai dengan adanya Sidang Menteri Luar Negeri yang diselenggarakan oleh Organisasi Konferensi Islam di Pakistan pada Desember 1970. Mesir 
mengajukan proposal pendirian International Islamic Bank for Trade and Development dan proposal pendirian Federation of Islamic Banks. Setelah mendapatkan pembahasan dari 18 negara Islam, akhirnya proposal tersebut diterima. Pada tahun 1975, Sidang Menteri Keuangan yang diselenggarakan oleh Organisasi Konferensi Islam di Arab Saudi menyetujui pendirian Islamic Development Bank.

Di Indonesia, sebagaimana diamanatkan oleh Pancasila dan Undang-Undang Dasar Negara Republik Indonesia Tahun 1945, tujuan pembangunan nasional adalah terciptanya masyarakat adil dan makmur berdasarkan demokrasi ekonomi dengan mengembangkan sistem ekonomi yang bertumpu pada mekanisme pasar yang berkeadilan. Guna mewujudkan tujuan tersebut, pelaksanaan pembangunan ekonomi nasional diarahkan pada perekonomian yang berpihak pada ekonomi kerakyatan, merata, mandiri, handal, berkeadilan, dan mampu bersaing di kancah perekonomian internasional. Agar tercapai tujuan pembangunan nasional dan dapat berperan aktif dalam persaingan global yang sehat, diperlukan partisipasi dan kontribusi semua elemen masyarakat untuk menggali berbagai potensi yang ada di masyarakat guna mendukung proses akselerasi ekonomi dalam upaya merealisasikan tujuan pembangunan nasional.

Dalam Prinsip perbankan syariah merupakan bagian dari ajaran Islam yang berkaitan dengan ekonomi. Salah satu prinsip dalam ekonomi Islam adalah larangan riba dalam berbagai bentuknya dan menggunakan sistem antara lain prinsip bagi hasil. Dengan prinsip bagi hasil, bank syariah dapat menciptakan iklim investasi yang sehat dan adil karena semua pihak dapat saling berbagi, baik keuntungan maupun potensi risiko yang timbul, sehingga akan menciptakan posisi yang berimbang antara bank dan nasabahnya. Dalam jangka panjang, hal ini akan mendorong pemerataan ekonomi nasional karena hasil keuntungan tidakhanya dinikmati oleh pemilik modal saja, tetapi juga oleh pengelola modal. 


\section{Peranan system perbankan syariah di Indonesia.}

Perbankan Syariah yang telah dicanangkan oleh OJK mempunyai tujuan mewujudkan masyarakat Indonesia yang bebas riba. Oleh karena itu, bank syariah memiliki peranan yang sangat penting untuk membangun pemahaman mengenai kemanfaatan produk dan jasa perbankan syariah karena perkembangan bank syariah tidak terlepas dari peran aktif bank syariah dalam melakukan sosialisasi dan edukasi kepada masyarakat.

Perbankan syariah memegang peran yang sangat penting dalam mendorong laju pertumbuhan ekonomi Indonesia, hal ini dapat dilakukan dengan menumbuhkan sektor investasi melalui dana pihak ketiga (DPK) dan menumbuhkan pembiayaan melalui pembiayaan yang diberikan (PYD) kepada masyarakat. Di Indonesia perkembangan perbankan syariah sangat baik dan mengalami pertumbuhan yang sangat pesat dari tahun ke tahun. Pertumbuhan perbankan syariah yang sangat pesat ini dapat dilihat dari perkembangan Bank Umum Syariah (BUS), Unit Usaha Syariah (UUS), dan Bank Pembiayaan Rakyat Syariah (BPRS) yang mengalami pertumbuhan yang sangat pesat dari tahun ke tahun.

Ekonomi dalam islam adalah ilmu yang mempelajari segala perilkau manusia dalam memenuhi kebutuhan hidupnya dengan tujuan falah (kedamaian dan kesejahteraan duniaakhirat). Maka dapat disimpulkan bahwa masalah ekonomi dalam islam adalah masalah menjamin berputarnya harta diantara manusia agar dapat memaksimalkan fungsi hidupnya sebagai hamba allah yang mencapai kedamaian atau falah di dunia dan di akhira inilah yang menjadi masalah ekonomi saat ini. Oleh karena itu, perbankan syariah berperan penting dalam upaya meningkatkan kesejahteraan masyarakat. Mengingat bank memiliki fungsi lembaga intermediasi. Perbankan syariahdalam menjalankan kegiatan operasionalnya 
berdasarkan prinsip-prinsip islam dimana jika benar-benar dilaksanakan dengan sebaikbaiknya tentu akan memberikan dampak positif untuk mensejahterakan masyarakat luas.

a. Prinsip fundamental system perbankan syariah

Syariah adalah aturan yang diturunkan dari Alquran dan Sunnah Nabi Muhammad. Pengembangan selanjutnya menyangkut aturan hukum disajikan dalam jurisprudeni Islam atau ulama fikih dalam kerangka menjabarkan aturan Alquran dan Sunnah. Beberapa prinsip dasar perbankan syariah yang diterapkan adalah sebagai berikut:

1. Larangan riba dan bunga.

Larangan riba dan bunga dimulai sejak adanya pelarangan riba karena diharamkan oleh Alquran dan Alhadist. Alquran mengharamkan riba dalam empat ayat yaitu ayat Qs. 30:39 di Mekah dan yang ketiga lainnya (Qs. 4:161, Qs. 3:130-1332 dan Qs. 2:275-281) adalah di Madinah. Yang terakhir muncul menjelang wafatnya Rasullullah SAW adalah Qs. 2:275-281. Ayat tersebut melarang dengan keras mengambil riba.

2. Larangan tersebut didasarkan pada argumentasi keadilan sosial, persamaan, dan hak milik 116 At-Tijaroh Volume 2, No. 1, Januari-Juni 2016 Islam membolehkan pendapatan dari laba tetapi melarang pembebanan bunga. Laba menandakan kesuksesan wirausaha dan menciptakan penambahan kekayaan. Sementara itu bunga adalah suatu biaya yang dibebankan pada peminjamnya tanpa mempedulikan bagaimana dengan hasil aktivitas bisnis apakah untung atau rugi. Prinsip keadilan sosial dalam pandangan Islam menuntut pemilik dana dan pengguna dana untuk berbagi atas keuntungan demikian juga bila terjadi kerugian. Islam memberikan panduan bahwa proses akumulasi kekayaan dan distribusi ekonomi terbentuk secara fair dan benar.

\section{Berbagi risiko}


Islam mendorong para pemilik dana menjadi investor sehingga konsep investor ini merupakan pengganti konsep kreditur dalam kerangka perbankan konvensional. Penyedia modal dan usahawan berbagi atas risiko bisnis, demikian pula mereka akan berbagi keuntungan ketika mendapatkan laba. Bentuk-bentuk pembiayaan syariah yang paling menguntungkan adalah cara bagi hasil mudharabah dan musyarakah. Pada kedua bentuk pembiayaan syariah tersebut, pemilik modal menyediakan dana bukan sebagai pemberi pinjamin tetapi lebih sebagai investor. Pembiayaan berdasarkan ekuitas diyakini dapat menjadi bagian yang tidak terpisahkan dari strategi untuk mengaktualisasikan tujuantujuan kemanusiaan seperti pemenuhan kebutuhan pokok, full employment, distribusi pendapatn dan kekayaan yang berkeadilan dan stabilitas ekonomi.

4. Uang sebagai modal ,potensiale Dalam pandangan Islam, uang merupakan modal „potensial ${ }^{\text {ee }}$. Modal nyata yang jika digabungkan dengan sumber daya lain untuk melakukan aktivitas produktif sangat bermanfaat. Islam mengakui nilai kontribusi uang, ketika uang bertindak sebagai modal yang digunakan untuk aktifitas usaha.

5. Larangan perilaku spekulatif Sistem keuangan Islam melarang penimbunan (hoarding) dan melarang transaksi yang ada unsur ketidakpastian, perjudian dan berisiko ekstrim. Peranan Perbankan... Ikhwanuddin Harahap 117

6. Kesucian akad (kontrak) Islam menegakkan kewajiban sesuai dengan akad (kontrak) dan keterbukaan informasi sebagai tugas suci. Tujuannya adalah untuk mengurangi risiko dari informasi asimetrik dan moral hazard.

7. Aktivitas yang disetujui syariah Investasi hanya boleh dilakukan pada aktifitas bisnis yang tidak melanggar ketentuan-ketentuan syariah. Contohnya: investasi bisnis yang berkaitan dengan minuman keras, perjudian dan barang haram yang memang dilarang dalam agama Islam. 
Adapun prinsip-prinsip operasional bank syariah adalah sebagai berikut :

1. Prinsip Mudharabah Perjanjian antara dua pihak, yaitu pihak pertama sebagai pemilik dana (shahibul maal) dan ihak keuda sebagai pengelola dana (mudharib) untuk mengelola suatu kegiatan ekonomi dengan menyepakati nisbah bagi hasil atas keuntungan yang akan diperoleh sedangkan kerugian yang timbul merupakan risiko pemilik dana sepanjang tidak terdapat bukti bahwa mudharib melakukan kecurangan atau tindakan yang tidak amanah (misconduct).

2. Prinsip Musyarakah Perjanjian antara pihak-pihak untuk menyertakan modal dalam suatu kegiatan ekonomi dengan pembagian keuntungan atau kerugian sesuai nisbah yang disepakati. Musyarakah dapat bersifat tetap atau bersifat temporer dengan penurunan secara periodik atau sekaligus pada akhir masa proyek.

3. Prinsip Wadie ah Pihak pertama menitipkan dana atau benda kepada pihak kedua selaku penerima titipan dengan konsekuensi titipan tersebut sewaktu-waktu dapat diambil kembali dan peniip dapat dikenakan biaya penitipan.

4. Prinsip Jual Beli Terdiri atas murabahah yaitu akad jual beli antara kedua belah pihak yang didalamnya pembeli dan penjual menyepakati harga jual yang terdiri atas harga beli ditambah ongkos pembelian dan keuntungan bagi penjual. 118 At-Tijaroh Volume 2, No. 1, Januari-Juni 2016 Murabahah dapat dilakukan secara tunai dan bisa juga secara bayar tangguh atau bayar dengan angsuran.

5. Prinsip Kebajikan Penerimaan dan penyaluran dana kebajikan dalam bentuk zakat, infak, sedekah dan lainnya serta penyaluran alqardul hasan yaitu penyaluran dan dalam bentuk pinjaman untuk tujuan menolong golongan miskin dengan penggunaan produktif tanpa diminta imbalan, kecuali pengembalian pokok utang. 
b. Hubungan Perbankan Syariah dengan Perekonomian Indonesia.

Kata bank berasal dari kata banque dalam bahasa Perancis dan dari banco dalam bahasa Italia, yang artinya peti atau lemari ayau bangku. Kata peti atau lemari menyiratkan fungsinya sebagai tempat menyimpan benda-benda berharga. Ternyata sejak dahulu kala sudah ada kebiasaan orang yang ingin melakukan pertukaran uang dilayaninya di pinggir jalan dengan satu meja, orang yang duduk Peranan Perbankan Ikhwanuddin Harahap 119 menghadap meja tersebut disebut „,bancheriie ${ }^{e e}$ kemudian kini menjelma menjadi bankir. Di dalam Alquran sendiri, istilah bank tidak disebutkan secara eksplisit namun unsur-unsurnya seperti: strukutr manajemen, fungsu, hak dan kewajiban dimana semuanya dijelaskan dengan jelas seperti zakat,shadaqah, ghanimah (rampasan perang), ba'i (jual beli) dan dayn (utang dagang), maal (harta) dan sebagainya yang memiliki kegiatan tertentu dalam kegiatan ekonomi.

Dalam menjalankan kegiatan operasionalnya, perbankan syariah tidak diperkenankan melanggar prinsip-prinsip fundamental dalam agama Islam. Sebut saja riba, jika dilakukan akan ada dampak negatif terhadap ekonomi maupun sosial masyarakat, diantaranya adalah :

\section{Dampak Ekonomi}

a. Inflasi

Komponen bunga dimasukkan dalam komponen biaya. Perusahaan yang memperoleh pinjaman dari bank, harus membayar sejumlah bunga. Biaya bunga dibebankan pada komponen harga pokok. Harga pokok akan berpengaruh pada harga jual barang, sehingga harga jual barang meningkat karena di dalamnya ada unsur bunga yang dibebankan kepada pembeli. Secara nasional pembebanan bunga kepada pembeli akan menaikkan harga, sehingga akan menyebabkan inflasi. 


\section{b. Ketergantungan Ekonomi}

Peminjam akan selalu membayar bunga kepada pemberi pinjaman. Pembayaran pinjaman pada umumnya tidak dilakukan seara sekaligus, akan tetapi dilakukan dengan cara angsuran. Angsuran pinjaman terdiri dari unsur pengembalian pokok pinjaman dan pembayaran bunga selama jangka waktu tertentu.

\section{Dampak Sosial Masyarakat}

a. Ketidakadilan

Bunga akan diterima oleh pihak pemberi pinjaman sedangkan pihak peminjam akan membayar bunga. Pemberi pinjaman akan menerima bunga sebagai pendapatan. Sebaliknya, peminjam akan membayar bunga sebagai pengeluaran. Pemberi pinjaman akan selalu 120 At-Tijaroh Volume 2, No. 1, Januari-Juni 2016 diuntungkan karena mendapat bunga dari peminjam, sebaliknya peminjam akan selalu rugi karena dibebani biaya atas uang yang dipinjam.

b. Ketidakpastian

Peminjam akan selalu membayar bunga sesuai dengan persentase yang telah diperjanjikan. Pemberi pinjaman tidak mempertimbangkan apakah dana yang dipinjamkan kepada peminjam telah digunakan untuk usaha dan menghasilkan keuntungan. Pemberi pinjaman selelu mendapatkan keuntungan meskipun peminjam menderita kerugian. Di dalam perjanjian, dipastikan bahwa peminjam akan mendapat keuntungan atas uang pinjamannya padahal usahan yang dilakukan peminjam masih mengandung unsur ketidakpastian apakah akan mendapat keuntungan atau menderita kerugian. 
3, Peranan Perbankan Syariah dalam Upaya Peningkatan Kesejahteraan Masyarakat

Perbankan syariah menerapkan prinsip-prinsip keuangan Islam yang tepat untuk mewujudkan financial inclusion dan mendorong tingkat pemerataan dalam meningkatkan pertumbuhan nasional serta kesejahteraan bersama. Indonesia sebagai salah satu negara dengan populasi muslim terbesar di dunia, namun memang kontribusinya terhadap perekonomian belum sepenuhnya terwujud. Tentu hal itu masuk akal, karena perbankan syariah di Indonesia sendiri tergolong masih baru dibandingkan negara-negara mayoritas muslim lainnya di dunia.

Namun demikian, bukan berarti perbankan syariah tidak memiliki kontribusi terhadap peningkatan kesejahteraan masyarakat. Saat ini perbankan syariah terus mengalami pertumbuhan yang positif. Dengan prinsip-prinsip fundamental berdasarkan ajaran agama Islam, sebenarnya perbankan syariah sangat mungkin menjadi cara untuk meningkatkan kesejahteraan masyarakat. Dengan dilarangnya berbagai praktik yang dapat merugikan masyarakat maka sebenarnya semakin besar peluang terciptanya perekonomian yang sehat dan positif.

\section{Dasar Hukum SistemPerbankan Syariah}

Aspek Hukum Undang-undang Perbankan Syariah UU No. 21 Tahun 2008, dilihat dari sisi filosofi yuridis dan Sosiologis pada dasarnya telah menjawab kebutuhan rasa Keadilan Ummat Islam sebagai konsekuensi fluralisme hukum yang hidup dan tumbuh dalam dinamika masyarakat Indonesia. Sedangkan dari pendekatan yuridis formalistik melalui payung hukum UU No.3 tahun 2006 dan UU No.4 tahun 2004 implementasinya menuntut hakim dalam mewujudkan dan menegakkan keadilan, hendaknya mengetahui dan memahami aspirasi serta nilai-nilai yang hidup dalam masyarakat dan orientasi, keadilanlah yang harus dikedepankan bersama-sama dengan orientasi kepastian hukum dan kemanfaatan. 


\section{Aspek Yuridis Perbankan Syariah}

Peradilan Agama, secara yuridis normatif merupakan amanat konstitusi Undangundang NKRI 1945 Pasal 24, Pasal 25, yang konkritisasi formalitasnya Undang-Undang Nomor 3 Tahun 2006 dan dipayungi oleh Undang-Undang Nomor 48 Tahun 2009 tentang Kekuasaan Kehakiman. Undang-undang perbankan syariah, jika diteropong dari aspek yuridis merupakan hukum yang baik, karena hukum yang baik adalah hukum yang mempunyai kekuatan yuridis yang memberikan kepastian hukum. Dalam rangka mewujudkan kepastian hukum unsur penegakan hukum dari Friedman (substansi,struktur dan kultur) penekanan unsur manusia merupakan pelaku utama dalam segala kegiatan untuk mewujudkan keadilan.

Undang-undang Nomor 21 Tahun 2008 dilihat dari pendekatan yuridis formalistik dengan payung hukum (UU No. 3 Tahun 2006, UU No. 4 Tahun 2004) tentu pemahaman hukum dalam konteks kehidupan masyarakat Indonesia yang sedang berubah, lalu lintas kebutuhan yang semakin beragam dan kompleks merupakan realitas tuntutan kebutuhan hukum dan hukum bukan sekedar untuk menjadi bahan pengkajian secara logis rasional melainkan hukum dibuat untuk dijalankan. Perwujudan tujuan, nilai-nilai ataupun ide-ide yang terkandung dalam peraturan hukum merupakan suatu kegiatan yang tidak berdiri sendiri, melainkan mem-punyai hubungan timbal balik yang erat dengan masyarakat.

2. Implementasi Sosiologis Perbankan Syariah

Berdasarkan aspek politik hukum lahirnya Undang-undang Perbankan Syariah Nomor 21 Tahun 2008, masih menyisakan pekerjaan rumah di antaranya tahap yuridis, tahap kelembagaan dan tahap mekanik. Tahap yuridis, memfokuskan pada bagaimana hukum yang 
tertulis (legal formal) dapat berjalan, ditegakan di tengah-tengah masyarakat untuk mencapai keadilan. Tentu aspek penegak hukum yang oleh Friedman dipengaruhi oleh sub sistem substansi, struktur dan kultur yang akan menjawab efektif tidaknya suatu perundangundangan. Oleh karena itu dalam tahap ini ada kaitan erat dengan asas-asas hukum yang lazim kita kenal dengan istilah nilai dasar hukum yaitu: kemanfaatan, keadilan dan kepastian hukum.

Hukum dalam menjalankan fungsinya sebagai pengatur kehidupan bersama manusia harus menjalani sebuah proses yang panjang dan melibatkan berbagai aktivitas dengan kualitas yang berbeda-beda. Hukum harus diturunkan dari dimensi abstrak ke dimensi konkrit, dalam hal ini UU No. 21 Tahun 2008 agar keberadaannya dapat dirasakan oleh masyarakat.

Landasan Hukum perbankan Syariah :

a. Dalil al-qur'an

tidak ada ketentuan yang spesifikasi mengenai pendirian bank syariah sehingga penulis memberikan landasan hukum dari prinsip tolong menolong/kerja sama serta ayat yang berkaitan dengan riba yang dalam prakteknya sangat berkaitan erat dengan oprasional bank syariah itu sendiri

1). Q.S Al-Maa-idah 2

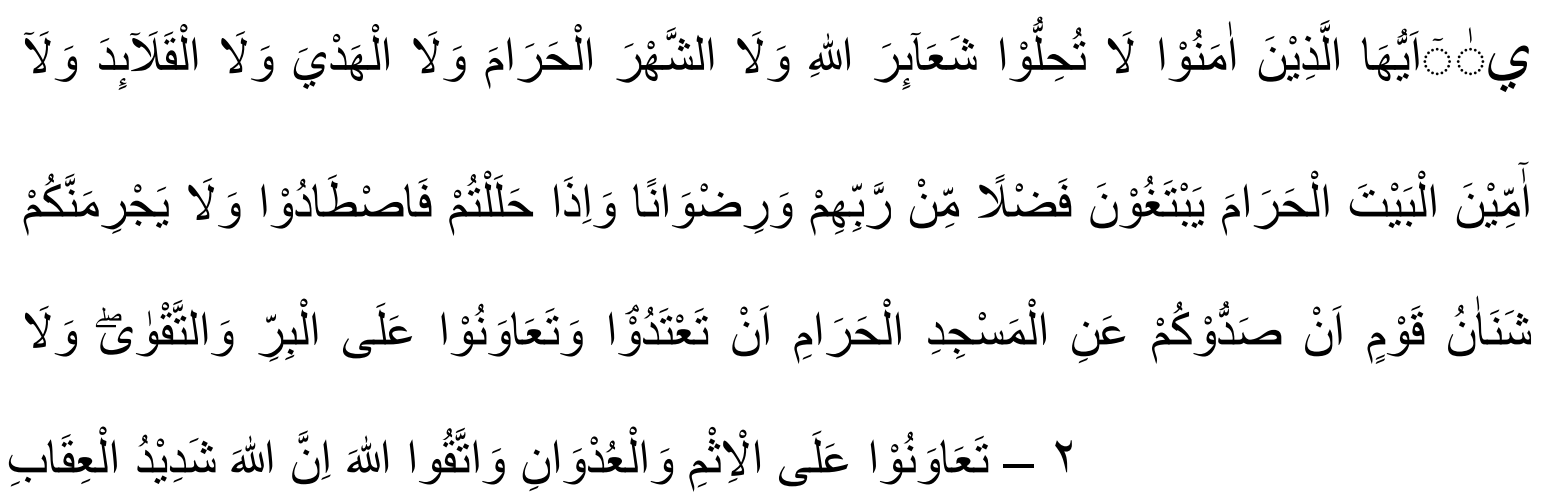


Artinya: "Wahai orang-orang yang beriman! Janganlah kamu melanggar syiar-syiar kesucian Allah, dan jangan (melanggar kehormatan) bulan-bulan haram, jangan (mengganggu) hadyu (hewan-hewan kurban) dan qala'id (hewan-hewan kurban yang diberi tanda), dan jangan (pula) mengganggu orang-orang yang mengunjungi Baitulharam; mereka mencari karunia dan keridaan Tuhannya. Tetapi apabila kamu telah menyelesaikan ihram, maka bolehlah kamu berburu. Jangan sampai kebencian(mu) kepada suatu kaum karena mereka menghalang-halangimu dari Masjidilharam, mendorongmu berbuat melampaui batas (kepada mereka). Dan tolong-menolonglah kamu dalam (mengerjakan) kebajikan dan takwa, dan jangan tolong-menolong dalam berbuat dosa dan permusuhan. Bertakwalah kepada Allah, sungguh, Allah sangat berat siksaan-Nya.”

2). Q.S Surat An-Nisaa 160-161

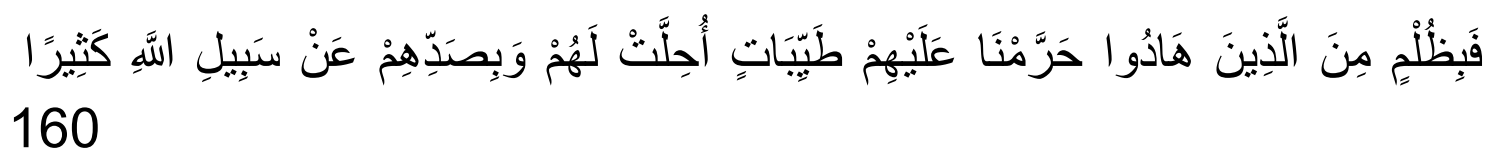

"Maka disebabkan kezaliman orang-orang Yahudi, Kami haramkan atas mereka (memakan makanan) yang baik-baik (yang dahulunya) dihalalkan bagi mereka, karena mereka banyak menghalangi (manusia) dari jalan Allah" (Q.S An-Nisa : 160)

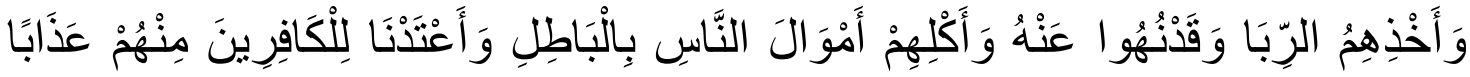 161 ألَأليمًا 161}

"Disebabkan mereka memakan riba. padahal sesungguhnya mereka telah dilarang darinya, dan karena mereka memakan harta orang dengan jalan yang batil. Kami telah menyediakan untuk orang-orang yang kafir di antara mereka itu siksa yang pedih." (Q.S An-Nisa : 161).

\section{b. Hukum Islam Positif Indonesia}


Landasan hukum pertama yang berlaku untuk pendirian bank syari'ah yaitu undangundang No.7 tahun 1992 tentang perbankan syari'ah yang memberikan kesempatan operasi bagi hasil. Setelah itu muncul undang-undang No.7 tahun 1992 tentang perbankan. Pada UU perbankan baru ini Bank Indonesia mengakui keberadaan bank konvesional dan bank syari'ah serta menerapkan Dual Banking system. Pengaturan bank syari'ah ini juga tersebar di berbagai UU dan peragturan bank Indonesia lainnya untuk menunjang kegiatan operasional bank missal terdapat pada UU perbankan Indonesia, PBI terntang kegiatan usaha berdasarkan prinsip syari'ah, PBI tentang akad penghimpunan dan penyaluran dana bagi bank yang melaksanakan kegiatan usaha berdasarkan prinsip syari'ah dan lain-lain. Landasan hukum yang terbaru undang-undang No.21 Tahun 2008 tentang perbankan syari'ah.

Beberapa faktor yang mempengaruhi upaya penegakan UU No. 21 Tahun 2008 di antaranya: kurangnya sumber daya manusia (SDM); aspek yuridis (perlunya UU materiil yang menjadi sumber rujukan); Kelembagaan, perlu perombakan yang cukup mendasar baik struktur, karir hakim dan lain-lain yang berkaitan dengan penguatan kelembagaan; aspek pemberdayaan masyarakat (pemahaman masyarakat tentang ekonomi syariah); aspek penciptaan mekanisme penyelesaian sengketa perbankan syariah; belum adanya standar dalam penerapan prinsip syariah dalam memecahkan masalah perbankan syariah; sentralisasi kebijakan dan kurangnya infrastruktur.

\section{Kesimpulan:}

System perbankan syari'ah di atas bahwa perbankan syari'ah di di indonesia adalah lembaga keuangan yang menjalankan aktivitas perbankan syari'ah murni yang ada kaitannya dengan kegiatan keagamaan dalam mendorong laju pertumbuhan ekonomi Indonesia. Dalam system perbankan syariah menerapkan prinsip-prinsip keuangan Islam yang tepat untuk mewujudkan tingkat pemerataan dalam meningkatkan pertumbuhan nasional serta kesejahteraan bersama. 
Indonesia sebagai salah satu negara dengan populasi muslim terbesar di dunia, namun memang kontribusinya terhadap perekonomian belum sepenuhnya terwujud. Tentu hal itu masuk akal, karena perbankan syariah di Indonesia sendiri tergolong masih baru dibandingkan negara-negara mayoritas muslim lainnya di dunia. 